Annals of Plant and Soil Research 22(4): 425-431 (2020)

https://doi.org/10.47815/apsr.2020.10016

\title{
Characterization of indigenous brinjal (Solanum melongena L.) lines usingmorphological traits under Jharkhand condition
}

\author{
NEHA RAJAN, SANDIP DEBNATH, AVIJIT KR. DUTTA*, BRIJESH PANDEY** AND AJEET K.R. \\ SINGH***
}

\begin{abstract}
Department of Genetics and Plant Breeding, PalliShikshaBhawan (Institute of Agriculture), Visva-Bharti, Sriniketan-731236, W.B, India.
\end{abstract}

Received: July, 2020; Revised accepted: September, 2020

\begin{abstract}
A total of 25 indigenous lines collected from different agroclimatic zones of Jharkhand were evaluated at Ranchi during rabi season of 2018-19 in randomized block design with three replications. The aim of present study was to assess the extent of genetic variation and identify most promising germplasm for improvement programme. Seventeen quantitative and forty qualitative characters were analysed as per DUS guidelines. Significant differences were recorded in most of the characters. The genotype RKML-11 exhibited highest number of primary branches (6.67) and produced maximum yield (38.54 $\left.\mathrm{t} \mathrm{ha}^{-1}\right)$. Maximum fruit weight was recorded in RKML-28 $(262.8 \mathrm{~g})$. RKML-35 showed maximum value of fruit diameter $(33.9 \mathrm{~cm})$ but had minimum number of fruits per plant (6.7). However, RKML-21 showed maximum fruits per plant but had smallest fruit size $(8 \mathrm{~cm})$. RKML-26 exhibited precocious bearing habit, it was also second-best genotype in terms of yield (37.7 $\left.\mathrm{t} \mathrm{ha}^{-1}\right)$. The lowest yield was recorded in the genotype RKML-25 $\left(8.8 \mathrm{t} \mathrm{ha}^{-1}\right)$. These accessions could be used as potential donors for hybridization program to develop high heterotic hybrids.
\end{abstract}

Keywords: Brinjal, morphological characterization, indigenous lines, Jharkhand.

\section{INTRODUCTION}

Brinjal (Eggplant, Aubergine) is a traditional crop of India. The Genus Solanum comprises approximately 2000 species, which include both tuber bearing and non-tuber bearing form Solanum melongena is an important edible species under non-tuber bearing form. Brinjal fruit contains carbohydrates, proteins, fibre and vitamins like thiamine, niacin, pantothenic acid and folacin as well as minerals like calcium, iron, potash, zinc, copper and manganese, thus it has fair nutritional importance. It is an indigenous crop of India, hence greatest level of diversity is found in country. Brinjal is a major vegetable crop of Jharkhand and it is cultivated round the year in the state. It is grown in 80.09 thousand hectare area in state with production of 252.60 thousand metric tons in 2017-18 (Horticulture Stat. Division2018). Phenotypic characterization with appropriate statistical tools increases the quality of obtained information from morphological traits. The study of morphological characters is helpful in assessing similarities and dissimilarities among the genotypes. The variations present in the genotype are pre- requisite of any breeding program of crop improvement. Ranchi, Gumla and Khunti districts are part of eastern plateau of Chotanagpur fall under Jharkhand State, which is blessed with rich floral diversity like wild fruits, wild vegetables, heirloom crop varieties, medicinal and aromatic plants. The Plateau also have significant amount of variability for fruit characteristics such as shape, size, color in solanacious vegetables i.e. brinjal. But no significant work has been carried out for documentation of indigenous vegetables like brinjal of Jharkhand. There is a need for identification and characterization of potentially valuable lines of brinjal available in state, for their utilization in development of improved high yielding cultivars or hybrid varieties. Despite environmental influences agro-morphological characterization is important technique for characterization of germplasms. Thus, a special emphasis has to be given in conservation and documentation of such land races which are in the level of extinction. Therefore, the present study was initiated to characterize indigenous brinjal lines using morphological traits in Jharkhand. 


\section{MATERIALS AND METHODS}

The investigation was conducted at the experimental field of RKMVERI, Ranchi. The experimental area is situated at $23^{\circ} 44^{\prime}$ latitude and $85^{\circ} 54^{\prime}$ longitude at an altitude of 651 meter sea level. The climate of the area ranges from semi humid to humid semi-arid and receives annual rainfall of $1200 \mathrm{~mm}$. Collection of promising germplasms was done on the basis of personnel interaction with experienced and progressive farmers during March to September 2017. Based on feedback from growers, seeds were collected from various (35 different) locations. To segregate pure lines based on fruit morphology, an experimental trial was conducted during October 2017 to May 2018 by selfing the lines.The lines were harvested separately according to their distinct fruit morphology. A total 35 germplasms were selected for further studies. All these indigenous lines were grown to characterize plant architecture, grain morphology and quality traits during October 2018 to May 2019. The experimental materials were grown in randomized block design with three replications. The seed of all genotypes were grown in nursery following plug trays method of nursery raising. The growing media consisted of coco pit, vermicompost and soil (1:1:1) was used in nursery. Four weeks old seedlings were transplanted to the main field at the spacing of $75 \times 50 \mathrm{~cm}$. In each plot, there were 20 plants in the area of $9 \mathrm{~m}^{2}$. The cultivation practices were followed as per Birsa Agricultural University, Ranchi recommendations. Necessary plant protection measures were taken to control disease and pests. Seventeen quantitative and forty qualitative characters were analysed as per DUS guidelines. The observations were taken from five randomly selected plants from each plot of each replication for all the quantitative characters under study except days to flower initiation, days to $50 \%$ flowering, days to fruit initiation and plant survival \% which were recorded on whole plot basis. Data were statistically analysed as per procedure described by Panse and Sukhatme (1985). The mean values of the quantitative descriptors were computed with OPSTAT statistical software (1998).

\section{RESULt AND DISCUSSION}

\section{Growth characters}

The plant height was recorded at first fruit attaining physiological maturity. Significant differences were recorded among 35 genotypes. RKML-34 produced tallest $(75.9 \mathrm{~cm})$ while lowest value was recorded in RKML-6 $(50.5 \mathrm{~cm})$. Number of primary branches varied between 2.67 and 6.67, where RKML-11 produced highest and RKML-33 minimum number of primary branches (Table 1). RKML-35 $(19.7 \mathrm{~cm})$ had maximum leaf length and was significantly superior over all the genotypes with minimum leaf length recorded in RKML-2 $(12.6 \mathrm{~cm})$. Maximum leaf width was observed in RKML-35 $(14.1 \mathrm{~cm})$ which was statistically at par with RKML-9 $(13.1 \mathrm{~cm})$ and significantly superior over rest of the genotypes and lowest leaf width was recorded in RKML-28 $(7.3 \mathrm{~cm})$. The range of petiole length was from 2.29 to $5.55 \mathrm{~cm}$. The longest petiole was found in RKML-35 $(5.55 \mathrm{~cm})$ and shortest in RKML-6 $(2.29 \mathrm{~cm})$. Plant canopy spread from North to South was recorded between 59.83 to $83.91 \mathrm{~cm}$ with highest in RKML-26 $(83.91 \mathrm{~cm})$ and it was significantly different from all the genotypes evaluated except RKML-5 (82.62cm). The minimum plant spread was recorded in RKML-10 $(59.83 \mathrm{~cm})$. In east west direction plant spread was recorded in range of 58.15 to $86.74 \mathrm{~cm}$. The RKML-5 (86.74 $\mathrm{cm}$ ) exhibited highest plant spread and RKML-10 $(58.15 \mathrm{~cm}$.) lowest in east west direction. Large variation in growth characters was also obtained by Das et al. (2017), Dash et al. (2019), Chithaguntiet al. (2018).

\section{Flower characters}

Floral characteristics (Table1) revealed that RKML-26 needed least days for flower initiation (56.7 days). The maximum days to flower initiation were recorded in genotype RKML-16 (87 days). RKML-26 has taken 63.7 days (minimum) to reach $50 \%$ flowering which was at par with RKML-31 (64 days) and significantly superior over the other genotypes studied. Maximum number of days to attain $50 \%$ flowering stage was recorded in RKML-16 (98.3). This trend of variation was in accordance with the findings of Konyak et al. (2019). 
Table 1: Performance of indigenous lines of brinjal in relation to growth and flower characters

\begin{tabular}{|c|c|c|c|c|c|c|c|c|c|}
\hline Genotype & $\begin{array}{l}\text { Pl. Ht. } \\
(\mathrm{cm})\end{array}$ & $\begin{array}{l}\text { No. of Pri. } \\
\text { branches }\end{array}$ & $\begin{array}{l}\text { Leaf } \\
\text { Length } \\
\text { (cm) }\end{array}$ & $\begin{array}{l}\text { Leaf } \\
\text { width } \\
\text { (cm) }\end{array}$ & $\begin{array}{l}\text { Petiole } \\
\text { length } \\
(\mathrm{cm})\end{array}$ & \begin{tabular}{|c|} 
Plant \\
Spread N- \\
S (cm)
\end{tabular} & $\begin{array}{c}\text { Plant } \\
\text { Spread E- } \\
\text { W }(\mathrm{cm})\end{array}$ & $\begin{array}{c}\text { Flower } \\
\text { Initiation } \\
\text { (DAT) }\end{array}$ & $\begin{array}{c}\text { Days to } \\
50 \% \mathrm{Fl} \text {. } \\
\text { (DAT) }\end{array}$ \\
\hline RKML-1 & 61.7 & 5.7 & 14.5 & 9.8 & 3.8 & 75.2 & 75.8 & 78.7 & 84.0 \\
\hline RKML-2 & 53.0 & 4.7 & 12.6 & 7.8 & 3.4 & 62.5 & 65.0 & 62.0 & 68.0 \\
\hline RKML-3 & 55.2 & 5.3 & 13.7 & 8.0 & 3.3 & 66.7 & 58.5 & 60.7 & 68.0 \\
\hline RKML-4 & 61.6 & 6.3 & 16.4 & 11.1 & 4.8 & 71.5 & 78.2 & 81.3 & 85.7 \\
\hline RKML-5 & 63.9 & 5.3 & 14.4 & 9.6 & 3.7 & 82.6 & 86.7 & 83.3 & 87.0 \\
\hline RKML-6 & 50.5 & 4.7 & 14.0 & 8.6 & 2.3 & 63.9 & 61.6 & 64.3 & 70.7 \\
\hline RKML-7 & 62.6 & 6.0 & 15.7 & 11.6 & 5.2 & 73.2 & 73.6 & 80.7 & 85.0 \\
\hline RKML-8 & 58.3 & 5.0 & 15.6 & 11.6 & 4.7 & 72.2 & 68.0 & 82.7 & 89.0 \\
\hline RKML-9 & 65.0 & 5.3 & 16.8 & 13.1 & 5.5 & 68.9 & 71.7 & 85.3 & 89.0 \\
\hline RKML-10 & 53.5 & 4.3 & 14.1 & 8.9 & 3.1 & 59.8 & 58.1 & 82.0 & 89.7 \\
\hline RKML-11 & 68.7 & 6.7 & 17.2 & 11.2 & 5.3 & 70.4 & 70.9 & 78.7 & 87.7 \\
\hline RKML-12 & 63.6 & 4.7 & 14.4 & 10.0 & 3.5 & 62.9 & 65.3 & 82.7 & 93.0 \\
\hline RKML-13 & 57.3 & 4.7 & 12.8 & 8.0 & 2.6 & 61.1 & 65.7 & 80.7 & 90.0 \\
\hline RKML-14 & 66.0 & 5.3 & 14.5 & 10.3 & 3.9 & 67.3 & 67.5 & 86.3 & 96.7 \\
\hline RKML-15 & 51.9 & 3.3 & 12.8 & 9.0 & 2.3 & 63.8 & 60.8 & 76.7 & 86.7 \\
\hline RKML-16 & 62.3 & 5.3 & 14.0 & 9.7 & 2.8 & 65.0 & 66.0 & 87.0 & 98.3 \\
\hline RKML-17 & 59.3 & 4.0 & 13.9 & 8.8 & 2.6 & 62.7 & 62.7 & 76.3 & 84.3 \\
\hline RKML-18 & 59.0 & 4.3 & 14.7 & 9.5 & 3.0 & 72.3 & 67.2 & 76.0 & 84.0 \\
\hline RKML-19 & 59.2 & 4.3 & 14.1 & 9.4 & 2.9 & 71.2 & 74.7 & 82.0 & 90.0 \\
\hline RKML-20 & 56.3 & 4.0 & 15.2 & 9.7 & 3.6 & 70.6 & 73.2 & 76.7 & 86.0 \\
\hline RKML-21 & 53.7 & 3.3 & 13.9 & 8.9 & 2.8 & 65.3 & 68.7 & 77.3 & 89.3 \\
\hline RKML-22 & 55.6 & 5.0 & 15.1 & 9.5 & 4.2 & 70.1 & 70.9 & 76.3 & 84.3 \\
\hline RKML-23 & 53.7 & 3.0 & 14.8 & 8.7 & 3.1 & 65.4 & 69.0 & 80.0 & 87.7 \\
\hline RKML-24 & 54.6 & 4.0 & 14.9 & 9.1 & 3.7 & 69.4 & 75.0 & 80.3 & 87.0 \\
\hline RKML-25 & 51.6 & 3.0 & 12.7 & 7.9 & 3.1 & 60.8 & 64.3 & 76.0 & 89.3 \\
\hline RKML-26 & 64.4 & 6.0 & 14.2 & 9.0 & 3.8 & 83.9 & 83.7 & 56.7 & 63.7 \\
\hline RKML-27 & 56.4 & 4.7 & 14.9 & 8.8 & 2.8 & 71.3 & 73.3 & 63.7 & 71.0 \\
\hline RKML-28 & 53.9 & 3.7 & 12.9 & 7.3 & 2.8 & 69.9 & 72.9 & 61.3 & 69.7 \\
\hline RKML-29 & 55.5 & 4.0 & 13.9 & 8.1 & 2.5 & 62.3 & 66.5 & 66.3 & 75.3 \\
\hline RKML-30 & 54.1 & 3.7 & 13.3 & 7.8 & 2.5 & 64.6 & 65.2 & 57.7 & 67.0 \\
\hline RKML-31 & 61.7 & 5.0 & 15.1 & 9.2 & 3.7 & 65.3 & 72.7 & 57.3 & 64.0 \\
\hline RKML-32 & 53.0 & 3.3 & 14.2 & 8.5 & 2.6 & 61.0 & 65.3 & 58.0 & 70.0 \\
\hline RKML-33 & 53.7 & 2.7 & 13.9 & 7.9 & 2.6 & 64.6 & 65.3 & 62.7 & 69.3 \\
\hline RKML-34 & 75.9 & 6.0 & 14.6 & 9.4 & 4.2 & 78.1 & 81.8 & 72.0 & 76.7 \\
\hline RKML-35 & 62.6 & 5.3 & 19.7 & 14.1 & 5.5 & 73.3 & 77.8 & 86.7 & 92.0 \\
\hline C.D. at $5 \%$ & 3.10 & 1.14 & 1.44 & 1.13 & 0.95 & 2.90 & 5.11 & 2.92 & 2.53 \\
\hline $\mathrm{SE}(\mathrm{m})$ & 1.09 & 0.40 & 0.51 & 0.40 & 0.33 & 1.03 & 1.81 & 1.03 & 0.90 \\
\hline
\end{tabular}

\section{Yield attributes and fruit yield}

The genotype RKML-26 (70.7 days) needed minimum days for fruit initiation and was significantly superior over rest of the genotypes except RKML-30 and RKML-32 (72 days). However, RKML-19 took maximum time for fruit initiation (102.7 days). Similar result was reported by Kumar et al. (2008). The genotype RKML 14 recorded significantly longest fruit $(22.6 \mathrm{~cm})$ while the smallest in the genotype RKML-21 $(8.0 \mathrm{~cm})$. Similar range of fruit length was observed by Syed et al. (2018) and Dash et al. (2019). The fruit diameter ranged from 18.9 to
$33.9 \mathrm{~cm}$. The genotype RKML 35 had maximum value of fruit diameter $(33.9 \mathrm{~cm})$ and minimum in RKML-23 $(10.9 \mathrm{~cm})$. These findings are in agreement with the result obtained by Chinthagunti (2018) and Dash et al. (2019). The data (Table2) was revealed that all the genotypes differed significantly in terms of fruit per plant. It varied from 6.7 to 40.9 with maximum in genotype RKML-21 (40.9) followed by RKML-23 (33.2) and RKML-29 (29.6). All these genotypes are primitive type having small and spiny fruits. The genotype RKML- 35 (6.7) had minimum fruits per plant followed by RKML8 (7.5) and RKML-9 (7.6). These lines are 
having large and oval size green fruit. These results are in conformity with the findings of Konyak et al. (2019). Single fruit weight among the studied genotypes ranged from 26.2 to 262.8 g. The genotype RKML-28 had recorded maximum fruit weight $(262.8 \mathrm{~g})$ followed by RKML-11 (212.4 g). Minimum fruit weight was observed in the genotype RKML-23 (26.2 g). Similar finding was observed by Das et al.(2017) and Chinthagunti et al.(2018). The yield data of 35 genotypes indicated that the range was from 8.8 to $38.5 \mathrm{t} \mathrm{ha}^{-1}$. The genotype RKML-11 $(38.5 \mathrm{t}$ $\mathrm{ha}^{-1}$ ) exhibited maximum yield followed by RKML-26 (37.7 $\mathrm{t} \mathrm{ha}^{-1}$ ) and RKML-34 (34.2 t ha $\left.{ }^{1}\right)$. RKML-11 was statistically at par with RKML 26 and superior to RKML-34 and other genotypes. The lowest value in terms of yield was recorded in genotype RKML-25 (8.8 $\left.\mathrm{t} \mathrm{ha}^{-1}\right)$. Konyak et al. (2019) and Dash et al. (2019) found similar result. RKML -5 had minimum number of seeds (275) in the fruits while genotype RKML-9 exhibited maximum number of seeds (3570.7). All genotypes showed significant difference for seeds per fruit. Similar variation in seeds per fruit was also obtained by Konyak et al. (2019) in their local varieties of brinjal. The plant survival rate was recorded maximum in the genotype RKML-2 (96.7\%) followed by RKML-13 (95\%) and RKML-20 (95\%). RKML-29 (62.8\%) was most susceptible to disease and pests so the survival rate was recorded minimum in this genotype

Table 2: Yield attributes and yield of brinjal genotypes

\begin{tabular}{|c|c|c|c|c|c|c|c|c|}
\hline Genotype & $\begin{array}{l}\text { Frt. I } \\
\text { (DAT) }\end{array}$ & $\begin{array}{l}\text { Fruit Length } \\
(\mathrm{cm})\end{array}$ & \begin{tabular}{|c|}
$\begin{array}{c}\text { Fruit Diameter } \\
(\mathrm{cm})\end{array}$ \\
\end{tabular} & $\begin{array}{l}\text { Fruit// } \\
\text { Plant }\end{array}$ & $\begin{array}{c}\text { Single frt. } \\
\text { Wt. (g) }\end{array}$ & $\begin{array}{c}\text { Seed per } \\
\text { fruit }\end{array}$ & $\begin{array}{l}\text { Plant Survival } \\
\text { rate (\%) }\end{array}$ & $\begin{array}{l}\text { Yield } \\
\left(\text { tha }^{-1}\right)\end{array}$ \\
\hline RKML-1 & 86.0 & 16.4 & 17.0 & 9.6 & 133.0 & 2127.0 & 81.7 & 26.2 \\
\hline RKML-2 & 74.7 & 14.1 & 15.8 & 14.3 & 103.7 & 2308.0 & 96.7 & 21.4 \\
\hline RKML-3 & 77.3 & 13.0 & 21.0 & 17.7 & 125.8 & 2301.0 & 75.0 & 21.4 \\
\hline RKML-4 & 93.3 & 17.3 & 27.0 & 8.6 & 205.9 & 2000.3 & 90.0 & 27.5 \\
\hline RKML-5 & 98.3 & 14.8 & 23.9 & 9.6 & 175.3 & 275.0 & 86.7 & 27.8 \\
\hline RKML-6 & 80.0 & 10.4 & 17.5 & 16.9 & 78.8 & 2109.7 & 73.3 & 24.4 \\
\hline RKML-7 & 93.3 & 14.6 & 18.5 & 12.3 & 112.2 & 1558.3 & 93.3 & 23.1 \\
\hline RKML-8 & 98.0 & 18.9 & 31.3 & 7.5 & 151.6 & 2099.3 & 88.3 & 17.3 \\
\hline RKML-9 & 96.0 & 16.0 & 28.8 & 7.6 & 150.1 & 3570.7 & 93.3 & 14.6 \\
\hline RKML-10 & 99.0 & 11.3 & 18.2 & 23.6 & 63.4 & 2127.0 & 63.3 & 11.7 \\
\hline RKML-11 & 85.7 & 18.0 & 26.9 & 13.2 & 212.4 & 1712.0 & 85.0 & 38.5 \\
\hline RKML-12 & 100.0 & 17.8 & 24.3 & 9.3 & 196.0 & 1582.7 & 86.7 & 14.7 \\
\hline RKML-13 & 97.3 & 17.1 & 17.9 & 16.7 & 73.8 & 2180.7 & 95.0 & 14.9 \\
\hline RKML-14 & 95.3 & 22.6 & 18.5 & 11.5 & 114.6 & 661.7 & 81.7 & 15.7 \\
\hline RKML-15 & 91.7 & 17.0 & 20.1 & 11.8 & 108.2 & 3476.7 & 75.0 & 17.7 \\
\hline RKML-16 & 101.7 & 14.7 & 30.5 & 15.3 & 125.8 & 1449.3 & 86.7 & 16.7 \\
\hline RKML-17 & 92.7 & 19.1 & 18.7 & 16.9 & 100.3 & 3103.3 & 91.7 & 12.6 \\
\hline RKML-18 & 97.3 & 10.6 & 16.3 & 27.5 & 47.1 & 1628.7 & 85.0 & 19.2 \\
\hline RKML-19 & 102.7 & 9.6 & 14.6 & 29.6 & 41.0 & 2236.0 & 78.3 & 17.7 \\
\hline RKML-20 & 90.7 & 8.4 & 16.5 & 27.9 & 27.0 & 2242.3 & 95.0 & 10.6 \\
\hline RKML-21 & 94.0 & 8.0 & 11.7 & 40.9 & 42.4 & 1373.7 & 85.9 & 17.7 \\
\hline RKML-22 & 92.0 & 9.9 & 14.1 & 18.2 & 54.5 & 1817.7 & 83.3 & 10.0 \\
\hline RKML-23 & 100.3 & 8.3 & 10.9 & 33.2 & 26.2 & 2387.7 & 91.7 & 16.8 \\
\hline RKML-24 & 94.7 & 8.7 & 17.4 & 23.2 & 92.3 & 2251.7 & 90.0 & 18.2 \\
\hline RKML-25 & 92.0 & 9.1 & 14.7 & 29.4 & 42.5 & 2633.7 & 76.7 & 8.8 \\
\hline RKML-26 & 70.7 & 13.1 & 24.6 & 26.5 & 106.9 & 2164.0 & 83.3 & 37.7 \\
\hline RKML-27 & 88.7 & 9.9 & 18.1 & 20.5 & 30.0 & 1487.3 & 78.3 & 15.4 \\
\hline RKML-28 & 80.7 & 8.9 & 14.3 & 24.2 & 262.8 & 1823.7 & 84.3 & 10.7 \\
\hline RKML-29 & 97.0 & 8.3 & 13.8 & 14.5 & 44.2 & 1296.3 & 62.8 & 15.9 \\
\hline RKML-30 & 72.0 & 10.3 & 18.3 & 19.7 & 50.8 & 1921.0 & 70.0 & 16.4 \\
\hline RKML-31 & 76.3 & 10.7 & 18.1 & 25.9 & 37.8 & 2975.0 & 88.3 & 19.1 \\
\hline RKML-32 & 72.0 & 9.0 & 14.7 & 19.3 & 39.5 & 1301.7 & 80.0 & 17.4 \\
\hline RKML-33 & 78.3 & 9.4 & 16.3 & 17.4 & 47.3 & 1014.0 & 75.0 & 17.9 \\
\hline RKML-34 & 85.0 & 17.0 & 31.7 & 12.6 & 204.8 & 2234.3 & 90.0 & 34.2 \\
\hline RKML-35 & 102.7 & 18.9 & 33.9 & 6.7 & 196.5 & 2154.7 & 91.7 & 18.0 \\
\hline C.D. at $5 \%$ & 2.65 & 1.90 & 1.89 & 3.04 & 16.29 & 86.11 & 18.06 & 3.21 \\
\hline $\mathrm{SE}(\mathrm{m})$ & 0.94 & 0.67 & 0.67 & 1.07 & 5.76 & 30.45 & 6.39 & 1.14 \\
\hline
\end{tabular}




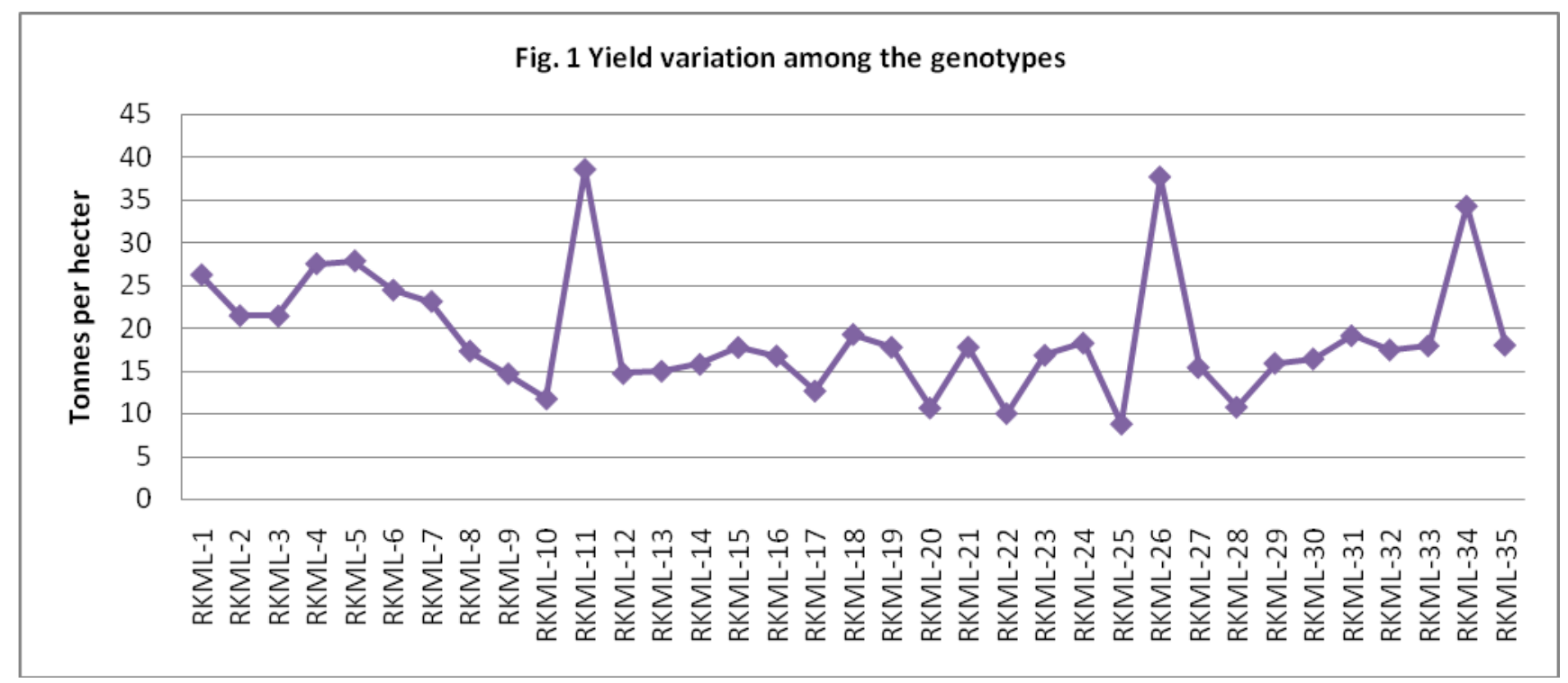

\section{Qualitative characters}

Leaf and stem: Among the genotypes, 27 expressed anthocyanin colourations on stem and rest of the lines (8) did not show any pigmentation. Stem pubescence was observed in all the 35 genotypes studied. All genotypes had entire type of leaf margin. The colour of leaf blade in all the genotypes was green except one genotype (RKML-22) which had purple colour of leaf blade. Anthocyanins and chlorophylls together are responsible for the dark violet to black pigmentation characteristic of many eggplant varieties (Dash et al., 2019). Most of the genotypes (27) had prickles on the leaf blade and 8 genotypes did not show prickles on their leaves. Brinjal Cultivars with smooth textured leaves were more preferred by the jassid compared to the cultivars with leaves having leathery texture and leathery texture with spines (Deole, 2008).

Flower inflorescence: The predominant flowering pattern was mixed type i.e. 1-3 in the same plant (33 genotypes) and 2 genotypes had showed clustering nature ( $>3$ flowers) of inflorescence. Flower colour varied from light purple to dark purple. Light purple flower was reported in 18 genotypes, purple flower in 12 genotypes and rest 5 genotypes had dark purple flower. These findings were also supported by Dissanayake et al. (2017).

Fruit: The data (Table 3 ) revealed that brinjal genotypes under study showed distinct variation in fruit shape and colour. Most of genotypes showed ovoid (42.8\%) and green fruits (71.4\%).
One genotype RKML1 had purple fruit and 9 other genotypes had green fruit with purple tinge. Whereas, 9 genotypes had globular fruit, 5 obovate, 5 cylindrical fruit and one with pear shaped dark purple fruit. Among genotypes with cylindrical fruit shape one genotype (RKML-1) had curve fruit and two showed slightly curved fruit. Solitary fruiting pattern was found in 29 genotypes, 2 had cluster pattern of fruiting and rest 4 expressed mixed type of fruiting. Two types of fruiting pattern were found in all the genotypes i.e. pendant $(82.9 \%)$ and semi pendant $(17.1 \%)$. Out of 35 genotypes, 29 genotypes had striped fruit and 6 genotypes showed patches on their fruit. Peduncle prickliness was present in 23 genotypes out of 35. Variation in colour and prickliness of calyx has been observed. Tiwari et al. (2016) studied morphological traits of brinjal landraces and grouped in to prickly and non-prickly types of accessions further classified on the basis of growth habit and fruit characters like shape and colour. Three types of flesh density were found in the fruit of genotypes. It varied from loose to compact. 3 genotypes had loose flesh, 12 genotypes with medium type of density in flesh and 20 had compact flesh density. Fruit creasing of calyx was strong in 18 genotypes, weak in 3 genotypes and medium type was found in 14 genotypes. Plant growth habit was reported to be semi-erect in maximum genotypes (65.7\%) and rest (34.3\%) showed spreading type growth habit. Similar trend of plant growth was obtainedby Chattopadhyay et al. (2011). Depending onthe cultivar, the fruit can vary from small to largeand pendulous, from oblong to round and might be such colours as green, white 
Table 3: Morphological descriptors, states and their frequency of indigenous lines of brinjal

\begin{tabular}{|c|c|c|}
\hline Descriptors & States & Relative Frequency \\
\hline Stem Anthocyanin Colour & $\begin{array}{l}\text { Absent } \\
\text { Present }\end{array}$ & $\begin{array}{l}22.86 \\
77.14\end{array}$ \\
\hline & Weak & 00.00 \\
\hline Stem Pubescence & $\begin{array}{l}\text { Medium } \\
\text { Strong }\end{array}$ & $\begin{array}{l}100.00 \\
00.00\end{array}$ \\
\hline & Entire & 100.00 \\
\hline Leaf Margin & Dentate & 00.00 \\
\hline & $\begin{array}{l}\text { Sinuate } \\
\text { Green }\end{array}$ & $\begin{array}{l}00.00 \\
97.14\end{array}$ \\
\hline Leaf Blade Colour & Purple & 2.86 \\
\hline Leaf Blade Prickliness & $\begin{array}{l}\text { Absent } \\
\text { Present }\end{array}$ & $\begin{array}{l}22.86 \\
77.14\end{array}$ \\
\hline Inflorescence/ No. of Flower & $\begin{array}{c}1 \text { to } 3 \\
>3 \\
\text { Greenish White }\end{array}$ & $\begin{array}{c}94.20 \\
5.71 \\
00.00\end{array}$ \\
\hline Flower Colour & $\begin{array}{l}\text { Light Purple } \\
\text { Purple } \\
\text { Dark Purple }\end{array}$ & $\begin{array}{l}51.43 \\
34.29 \\
14.28\end{array}$ \\
\hline & $\begin{array}{l}\text { Globular } \\
\text { Ovoid }\end{array}$ & $\begin{array}{l}25.74 \\
42.85\end{array}$ \\
\hline Fruit Shape & $\begin{array}{c}\text { Obovate } \\
\text { Pear Shaped }\end{array}$ & $\begin{array}{l}14.28 \\
2.85 \\
1428\end{array}$ \\
\hline & Green & $\begin{array}{l}14.20 \\
71.43\end{array}$ \\
\hline Fruit Colour & $\begin{array}{c}\text { Purple } \\
\text { Green Purple } \\
\text { Absent }\end{array}$ & $\begin{array}{l}2.86 \\
25.71 \\
91.43\end{array}$ \\
\hline Fruit Curvature & $\begin{array}{l}\text { Slight } \\
\text { Medium } \\
\text { Strong } \\
\text { Solitary }\end{array}$ & $\begin{array}{l}5.71 \\
2.86 \\
00.00 \\
82.86\end{array}$ \\
\hline Fruiting Pattern & $\begin{array}{l}\text { Cluster } \\
\text { Mixes }\end{array}$ & $\begin{array}{l}5.71 \\
11.43\end{array}$ \\
\hline Fruiting Position & $\begin{array}{c}\text { Pendent } \\
\text { Semi pendent }\end{array}$ & $\begin{array}{l}82.86 \\
17.14\end{array}$ \\
\hline Fruit Stripes & $\begin{array}{l}\text { Absent } \\
\text { Present }\end{array}$ & $\begin{array}{l}82.86 \\
17.14\end{array}$ \\
\hline Fruit Patches & $\begin{array}{l}\text { Absent } \\
\text { Present }\end{array}$ & $\begin{array}{l}17.14 \\
82.86\end{array}$ \\
\hline Fruit Size of Calyx & $\begin{array}{l}\text { Small } \\
\text { Medium } \\
\text { Large } \\
\text { Absent }\end{array}$ & $\begin{array}{l}5.71 \\
62.86 \\
31.43 \\
31.43\end{array}$ \\
\hline Calyx Prickliness & $\begin{array}{l}\text { Weak } \\
\text { Medium } \\
\text { Strong }\end{array}$ & $\begin{array}{l}11.43 \\
34.29 \\
22.85\end{array}$ \\
\hline Flesh Density & $\begin{array}{c}\text { Loose } \\
\text { Medium } \\
\text { Compact } \\
\text { Erect }\end{array}$ & $\begin{array}{c}8.57 \\
34.29 \\
57.14 \\
00.00\end{array}$ \\
\hline Plant Growth Habit & $\begin{array}{l}\text { Semi spreading } \\
\text { Spreading }\end{array}$ & $\begin{array}{l}65.71 \\
34.29\end{array}$ \\
\hline Seediness & $\begin{array}{l}\text { Low } \\
\text { Medium } \\
\text { High }\end{array}$ & $\begin{array}{c}5.71 \\
57.14 \\
37.14\end{array}$ \\
\hline
\end{tabular}

or yellow, among others or even striated shades and colour gradients. Fruit morphology was also studied by Dissanayake et.al. (2017) and Dash et al. (2019). These differences in morphological traits are generally occurs due to varietal effect and sometimes influenced by environmental condition too. 
Seed size and colour: Varietal preference also depends on seediness of fruit, which was high in $37.1 \%$ genotypes studied, medium in $57.1 \%$ and low in $5.7 \%$ genotypes. Das et al. (2017) also reported low to high range of seediness in brinjal. In Jharkhand, green ovoid/globular and less seediness type fruit of brinjal is preferred over purple long/ovoid type by consumer. From the findings of the present study it is revealed that, RKML-11 showed better performance in terms of yield and desired fruit morphology. Fruits have smooth and soft flesh too. RKMI-26 also produces at par yield with RKML 11 and it

\section{REFERENCES}

Chattopadhyay, A., Dutta, S. and Hazra, P. (2011) Characterization of genetic resources and identification of selection indices of brinjal (Solanum melongena L.) grown in Eastern India. Vegetable Crops Research Bulletin 74: 39-49.

Chinthagunti, H., Sarnaik, D.A. and Sharma, D. (2018) Evaluation of brinjal (Solanum melongena L.) genotypes for growth and yield parameters. International Journal of Current Microbiology and Applied Sciences 7 (12): 3095-3100.

Das, A., Pandit, K.M., Bairagi, S., Saha, S. and Muthaiah. K. (2017) A study on morphology of brinjal genotypes in Gangetic-Alluvial Zone of West Bengal, India. International Journal of Current Microbiology and Applied Sciences 6 (10): 3323-3331.

Dash, P.S., Singh, Jand, Sharma, D. (2019) Morphological characterization of brinjal (Solanum melongena L.) germplasm.Journal of Pharmacognosy and Phytochemistry 8(2): 1574-1578.

Deole, S. (2008) Screening of brinjal cultivars against jassid, Amrasca biguttula based on the leaf texture of the plant. Journal of Applied Zoological Research 19: 139-140.

Dissanayake, R.M.N., Darshana, H.G.B. and Marapana, W.M.W.S. (2017) genetic diversity analysis of brinjal (Solanum melongena L.) accessions grown in up country intermediate zone of Sri Lanka using morphological traits. Annals of Sri Lanka Department of Agriculture19 (2): 138-145.

Horticulture Statistics Division (2018) Horticulture Statistics at a Glance 2018. Department of Agriculture, Cooperation \& Farmers welfare, MoA \& FW, Gol. showed better earliness character. The other genotype viz. RKML 34, RKML-1, RKML-4, RKML-5, RKML-6, RKML-7, RKML-3,RKML-2 were good performer genotypes which have better yield potential than other genotypes.

Further it is concluded that these heirloom varieties of brinjal are the source of diversified flora. It needs further extensive and intensive investigation to suggest method of conservation as well as preservation of these genetic resources, as they may prove potential donors for hybridization programmes.

Khan, R., Singh, Y.V. (2014) Germplasm characterization in eggplant (Solanum melongena L.). Asian Journal of Horticulture 9(2): 356-359.

Konyak, W.L., Kanaujia, S.P., Jha, A. and Verma, S.K. (2019) Characterization of brinjal (Solanum melongena L.) genotypes for growth, yield and quality traits under foothill condition of Nagaland. Annals of Plant and Soil Research 21 (4): 380-385.

Kumar, G., Meena, B.L., Kar, R., Tiwari, S.K., Gangopadhyay, K.K., Bisht, I.S. and Mahajan, R.K., (2008) Morphological diversity in brinjal (Solanum melongena L.) germplasm accessions. Plant Genetic Resources: Characterization and Utilization 6 (3): 232-236.

Panse, V.G., Sukhatme, P.V. (1985) Statistical method for agricultural workers. Indian Council of Agricultural Research, New Delhi (4h $4^{\text {th }}$. $), 158-162$.

Syed, S., Reddy, R.V.S.K., Begum, H. and Reddy, T.M. (2018) Performance of brinjal (Solanum melongena L.) genotypes for yield and quality traits under Southern zone of Andhra Pradesh.International Journal of Current Microbiology and Applied Sciences Special Issue 7: 4977-4985.

Tiwari, S.K., Bisht I.S., Kumar G. and Karihaloo J. L. (2016) Diversity in brinjal (Solanum melongena L.) landraces for morphological traits of evolutionary significance. Vegetable Science 43 (1): 106-111.

Tripathy, B., Sharma, D., Jangde, B.P. and Bhairwa, P.L. (2017) Evaluation of brinjal (Solanum melongena L.) genotypes for growth and yield characters under Chhattisgarh condition. The Pharma Innovation Journal 6(10): 416-420. 